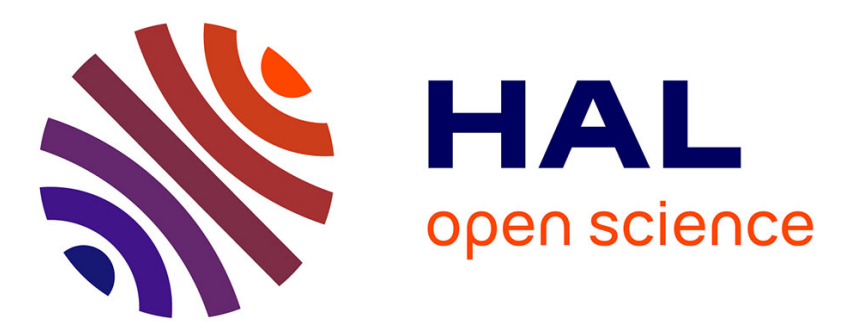

\title{
Wages and the Bargaining Regime under Multi-level Bargaining: Belgium, Denmark and Spain
}

\author{
Robert Plasman, Michael Rusinek, François Rycx
}

\section{To cite this version:}

Robert Plasman, Michael Rusinek, François Rycx. Wages and the Bargaining Regime under Multilevel Bargaining: Belgium, Denmark and Spain. European Journal of Industrial Relations, 2007, 13 (2), pp.161-180. 10.1177/0959680107078251 . hal-00570960

\section{HAL Id: hal-00570960 https://hal.science/hal-00570960}

Submitted on 1 Mar 2011

HAL is a multi-disciplinary open access archive for the deposit and dissemination of scientific research documents, whether they are published or not. The documents may come from teaching and research institutions in France or abroad, or from public or private research centers.
L'archive ouverte pluridisciplinaire HAL, est destinée au dépôt et à la diffusion de documents scientifiques de niveau recherche, publiés ou non, émanant des établissements d'enseignement et de recherche français ou étrangers, des laboratoires publics ou privés. 


\title{
Robert Plasman, Michael Rusinek and François Rycx
}

Université Libre de Bruxelles, BELGIUM

\section{Wages and the Bargaining Regime under Multi-level Bargaining: Belgium, Denmark and Spain}

\begin{abstract}
We use a harmonized matched employer-employee dataset to study the impact of the collective bargaining regime on wages in the manufacturing sector in three countries with a multi-level system of bargaining: Belgium, Denmark and Spain. Single-employer bargaining has a positive effect both on wage levels and on wage dispersion in Belgium and in Denmark. In Spain, it also increases wage levels but reduces wage dispersion. Our interpretation is that in Belgium and Denmark, single-employer bargaining is used to adapt pay to the specific needs of the firm while, in Spain it is mainly used by trade unions in order to compress the wage distribution. KEYWORDS: collective bargaining - manufacturing industry - trade unions - wage structure
\end{abstract}

\section{Introduction}

Institutions are an important determinant of the shape of the wage structure. Research using cross-country comparisons shows that the more centralized and/or coordinated the wage setting system, the more compressed is the wage distribution (Blau and Kahn, 2002; Teulings and Hartog, 1998; Wallerstein, 1999). This is due to two factors. Within centralized countries, multi-employer agreements set minimum wages that increase wages at the bottom of the wage distribution. In addition, multi-employer bargaining coordinates wage-setting, reducing inter-industry and inter-firm differentials. Research into the wage-structure effect of different bargaining regimes within countries where multi-employer bargaining is the prevalent bargaining mode, which is the case in most Western European countries, is much less extensive and produces more heterogeneous results. Under such settings most workers, irrespective of their union status, are covered by a nationwide and/or sectoral multi-employer agreement which sets minimum wages for defined categories of workers. Wage bargaining may also occur at the firm and/or establishment level, generally increasing wages above the 
national or industry standards. It is interesting to know the wage structure effect of the different bargaining regimes under multi-level bargaining since many actors, including the OECD (2004) and European Commission (2004) favour giving more weight to single-employer bargaining in the process of wage determination.

Previous studies have shown that single-employer bargaining increases wage levels relative to multi-employer bargaining (Cardoso and Portugal, 2003; Dell'Aringa and Lucifora, 1994a; Hartog et al., 2002; Palenzuela and Jimeno, 1996; Rycx, 2003). Findings concerning the effect of the bargaining regime on the dispersion of wages are much more heterogeneous. Theoretically, the dispersion of wages is expected to be higher for workers covered by single-employer agreements because they may increase inter-firm wage differentials by taking into account firm-specific characteristics and local economic conditions. This was observed in Sweden by Hibbs and Locking (1996), who found that the sensitivity of wage changes to local market conditions was significantly higher after the move from central to industry and local bargaining in 1982, and that wage dispersion has been increasing since then. For Belgium, Rycx (2003) found a lower dispersion of inter-industry wage differentials for firms covered only by a multi-employer agreement, compared to firms covered additionally by a single-employer agreement. This suggests that rent-sharing or efficiency wage practices are more common when there is a firm-specific agreement and that it increases the dispersion of wages. For Portugal, Cardoso and Portugal (2003) conclude that wage drift (ratio between actual and negotiated wages) works to overcome the constraints imposed by multi-employer bargaining, allowing firms wider flexibility in their wage policy.

Other studies, however, show the opposite. Dell'Aringa and Lucifora (1994b) found that local wage bargaining significantly reduces wage dispersion across establishments in Italy. They interpreted this as a sign of a greater desire for wage standardization among establishments covered by such an agreement. Checchi and Pagani (2004) also found that, in Italy, local bargaining reduces wage inequality.

Other researchers have focused on the effect of the bargaining regime on wage dispersion within firms. According to Rodriguez-Gutiérez (2001) this results from a bargaining process between the union and the employer, who have opposite preferences. Trade unions are in favour of higher wage levels and smaller dispersion, while employers prefer greater dispersion. This preference is explained by Tournament theory (Lazear and Rosen, 1981) which predicts that a more dispersed wage structure (resulting from performance-related pay or increased inter-occupational differentials) may provide incentives for workers to increase their effort. The fact that unionism reduces wage dispersion has been widely demonstrated empirically in Anglo-Saxon countries (Freeman, 1980). For Italy, Dell'Aringa and Lucifora (1994b) found that the within-firm wage dispersion decreases 
significantly as union density rises. A similar result has been found by Rodriguez-Gutiérez (2001) for firms covered by a company agreement in Spain. Overall, the final outcome of company bargaining on the withinfirm wage dispersion seems ambiguous: Dell'Aringa and Lucifora (1994b) found no difference in within-firm wage dispersion between firms covered only by a multi-employer agreement and those covered additionally by a company agreement. Conversely, Dominguez and Rodriguez-Gutiérez (2004) found that company bargaining reduces the within-firm wage dispersion in Spain. They attribute this result to the action of unions. Finally, Dell'Aringa et al. (2004), studying the effect of the bargaining regime on within-establishment wage inequality in Italy, Spain, Belgium and Ireland, found greater within-establishment inequality for establishments covered by a single-employer agreement. However, when a larger set of controls was included, the association was inverted or became statistically insignificant.

To sum up, this literature review shows that, compared to multi-employer bargaining, single-employer bargaining may increase or decrease wage dispersion, and this may happen through the modification of inter-firm wage differentials and/or within-firm wage dispersion.

In this article we study the wage structure effect of different bargaining regimes in the manufacturing sector in Belgium, Denmark and Spain. Multi-employer bargaining predominates in all three countries, but the bargaining structure and its history differ greatly between them. In Belgium and Denmark, single-employer bargaining has greatly expanded since the 1980s on the initiative of employers and the government. In Spain, by contrast, the structure of collective bargaining is more inert and has not changed very much since the Franco period, when company agreements were used as a tool for worker mobilization and for political struggle. Moreover, in Belgium and Denmark single-employer agreements always complement multi-employer agreements, whereas in Spain the two are mutually exclusive. Therefore, firms covered by a single-employer agreement in Spain often display a high union presence, but this is not necessarily the case in Belgium and Denmark. Previous studies show that wage dispersion is smaller under single-employer agreements in Spain while the opposite holds true for Belgium. This has never been studied in Denmark but it has been in another Scandinavian country (Sweden), where the effects are found to be similar to those in Belgium. Multi-country comparison is necessary to determine whether this divergence in results is due to national differences or to the use of different data and methodologies.

The first objective of this article is thus to provide reliable comparative results. More precisely, we compare the wage dispersion (standard deviation and inter-decile wage differentials) and the wage levels between workers covered by a multi-employer agreement and workers covered by a single-employer agreement. We use a unique harmonized multicountry dataset, the European Structure of Earnings Survey of 1995, 
which contains detailed information about wages, workers' and employers' characteristics and the level(s) of the collective agreements covering each firm. Although matched employer-employee datasets are now available for a number of individual countries, to the best of our knowledge the ESES is the only multi-country dataset with matched employer-employee data. Our results confirm previous findings that, compared to multi-employer bargaining, single-employer bargaining has a positive effect both on wage levels and on wage dispersion in Belgium and in Denmark; while in Spain, single-employer bargaining also increases wage levels but reduces wage dispersion. Our interpretation is that singleemployer agreements are mainly used in Denmark and Belgium to adapt pay to the specificities of the firm and to local economic conditions. In Spain, they are mainly used by unions to raise wages and to compress the wage distribution.

\section{Institutional Framework}

Multi-employer bargaining is the dominant bargaining regime in all three countries, but they differ in many other aspects. This section provides a short description of the collective bargaining system in each country. We also link the arguments presented in the previous section to each country's institutional characteristics, in order to derive some expectations about empirical results.

In Belgium and Denmark, collective bargaining occurs at three levels in a hierarchical manner, such that an agreement at one level cannot be less favourable than higher-level agreements. Inter-sectoral agreements cover the whole country. They set national minimum wages and a margin for wage increases, and define the framework for the lower bargaining levels. Sectoral agreements set industry standards (minimum wages by category of worker) for most of the employees in the industry concerned. Finally, wages may be increased at the level of the firm or establishment by a single-employer agreement. The importance of each level in the wage-setting process has varied over time. Until the 1980 s, wages were mainly determined by sectoral agreements. In the late 1960s, single-employer bargaining expanded, mainly because shop-floor unions sought pay increases in excess of higherlevel standard rates (Traxler et al., 2001). The economic crisis that followed the two oil shocks led employers in many countries to call for more flexible working conditions, leading to a second wave of bargaining decentralization in the mid-1980s with company-level determination of working time. A third wave in the 1990s was initiated by employers in order to tailor wages more strictly to the performance of the individual firm (Traxler et al., 2001). Because Belgium and Denmark are both small, open economies, they were severely hit by the economic crisis. 
In Denmark, there was a shift in many industry agreements from the standard rate system, where the sectoral agreement prescribes the wages actually earned, to the minimum pay system, where actual pay may well be higher. Between 1989 and 1995, the proportion of workers covered by the minimum pay system rose from 30 to 61 percent (Andersen, 2003). Pay increases at company level take often the form of a 'pay-sum bargaining': the aggregate size of the pay increase is determined by collective bargaining but its allocation is left to management (Traxler et al., 2001). In addition, the cost-of-living indexation mechanism was abolished in 1982, which reduced aggregate wage increases.

In Belgium, pay determination has also shifted from industry to singleemployer level. An explosion in company agreements took place between 1980 and 1985, the number rising from 341 to 3253. It declined after this period and stabilized around 2000 in the 1990s (Van Ruysseveldt and Visser, 1996). In order to preserve the competitiveness of Belgian firms, the government froze private-sector wages for the periods 1981-2. Wage increases above inflation were forbidden from 1983 to 1986. From 1984 to 1986, the cost-of-living indexation procedure was altered so that the first two percent each year was not compensated by a wage increase but instead used to supplement the social security fund. Finally, a new wage freeze was imposed in 1995-6, followed by a law on competitiveness imposing a ceiling for wage increases based on those in France, Germany and the Netherlands. The automatic link between prices and wages stayed in place, although the system changed in order to reduce aggregate wage increases (by excluding products like fuel, tobacco and alcohol from the price index).

Because single-employer agreements cannot set wages below national and industry standards, wage levels should on average, in both countries, be higher when a company agreement supplements the multi-employer agreement. We also expect inter-firm wage differentials to be higher for firms covered by a single-employer agreement because they can take into account firm-specific characteristics (size, profit, region) that are generally not among the criteria that define industry and national standards (those criteria are principally age, experience and occupation). Finally, the presence of a company agreement may be expected to increase wage dispersion, because in the 1990s many such agreements were initiated by employers in order to introduce new flexible pay practices.

In Spain, there was no inter-sectoral agreement at the time of the survey (these occurred however between 1977 and 1986 and were reintroduced in 1997). Working conditions were determined either by a sectoral or a company agreement. Following the 'no competition' principle, the two regimes deal with the same type of subjects and there is no division of responsibility between them (EIRO, 1997). Hence in contrast to Belgium and Denmark, a firm covered by a company agreement is not constrained by 
the industry agreement (though the 1997 inter-sectoral agreement improved coordination between the different bargaining regimes).

These conditions were in place from the legalization of collective bargaining in 1958. Until the death of Franco in 1975, collective bargaining was strongly controlled by the government. Industry agreements covered most of the workforce, but were much less respected than company agreements which were the result of almost free collective bargaining between employers and works councils. This is why trade unions (which were illegal during this period) attached much more importance to company bargaining, which was also used as a tool for worker mobilization and political struggle (Toharia, 1986). The percentage of the workforce covered by company agreements has been fairly stable over time, signalling a certain inertia in the structure of collective bargaining.

During the 1990s, while an expansion of single-employer agreements occurred in many countries, in Spain there was a decrease: 15 percent of employees were covered by a company agreement in 1990, but only 11 percent in 2001. Conversely the percentage of workers covered by industry agreements rose from 85 to 89 percent. In fact, employers' need for more pay flexibility is met by a multi-employer bargaining regime which is less binding on companies than single-employer agreements. ${ }^{1}$ For example, since 1994 opt-out clauses have allowed firms covered by a sectoral agreement to pay wages below industry standards in the case of economic difficulties. Hence the existence of a company collective agreement is still associated with greater trade union presence. According to Garcia-Serrano and Mallo (2002: 74), more than 80 percent of collective agreements at plant/firm level are initiated by works councils; 'the existence of this sort of agreement is a proxy variable for an organized action of workers' representatives'. Rodriguez-Gutiérez (2001) reports, for the period 1990-4, an average union density rate of 36 percent in firms covered by a company agreement, far above the national average of 11 percent (OECD, 2004). ${ }^{2}$ Moreover, company agreements are more often concluded in large firms (Izquierdo et al., 2003), where unions are traditionally better organized.

To summarize, there are two mutually exclusive bargaining regimes in Spain, with single-employer bargaining in firms with a higher union presence, while multi-employer bargaining is less binding for companies. Therefore, the wage structure effect of the bargaining regime in Spain may resemble that in Anglo-Saxon countries: we would expect wages to be higher when the firm is covered by a company agreement. We would also expect the within-firm wage dispersion to be lower. Inter-firm wage differentials may also be lower under the company agreement regime because of the trade union desire for standardization. Moreover, a majority of industry agreements are regional or provincial. In 1995, 59 percent of all workers covered by a collective agreement were covered by a local, provincial or regional industry agreement while national agreements 
covered only 27 percent of all workers (Izqierdo et al., 2003). Large firms, which may have establishments in different regions, are often covered by a company agreement, which sets identical conditions for the different regional establishments; so regional differentials may be lower under company agreements.

\section{Data}

This study is based on the 1995 European Structure of Earnings Survey, produced by Eurostat. This unique harmonized survey contains a wealth of information provided by the management of establishments, both on the firm characteristics (sector of activity, number of workers, region, form of economic control) and on the individuals they employ (age, level of education, paid hours, gender, occupation). It is representative of all establishments employing at least 10 workers across the economy, with the exception of agriculture and public services. ${ }^{3}$ This dataset provides information on the level or levels of collective agreement covering each establishment. Wage data relate to actual pay, not just negotiated rates, and include annual bonuses. This is relevant to our study because in many single-employer agreements, wage supplements are paid through bonuses (13th month, profit-sharing, productivity premium). On one hand, this conforms to the definition of wages that is currently used in the literature, so that we can compare our results with previous findings. On the other, we must be cautious when interpreting our results because pay levels may be the outcome of other processes besides collective bargaining. ${ }^{4} \mathrm{We}$ restrict our analysis to the manufacturing sector in order to minimize this problem, because we think that the differences between actual pay and negotiated rates of pay are higher in most service sectors. However, this difference may be more important for the wages observed in the industry agreements in Spain, because of the less binding nature of those agreements for companies.

Focusing on one sector has the additional advantage of estimating the effects of the bargaining regime on a sample of homogeneous individuals. Indeed, we think that these effects may differ greatly depending on the type of firm, worker and industry agreement. Moreover, manufacturing is the key bargaining sector in Denmark, setting the benchmark for agreements in other sectors (Andersen and Mailand, 2005). We also exclude workers who are not covered by any agreement, as well as by those that cannot be classified as single or multi-employer agreements (for instance, an industry may contain a single firm). Finally, we exclude workers belonging to a category (occupation or industry) not present in one of the two regimes within a country. In total, this corresponds to a reduction of seven, six and two percent respectively for the Belgian, Danish and Spanish samples. ${ }^{5}$ 
Several interesting points may be highlighted in the analysis of the dataset. In all three countries, wages are on average significantly higher under single-employer agreements. The standard deviation of log wages is smaller under single-employer than under multi-employer agreements in Spain. The opposite result is found for Denmark. No significant difference in standard deviation can be seen for Belgium. Seniority in the company is on average six years greater under company agreements than under industry agreements in Spain, while the difference in seniority between the two regimes is much smaller in Belgium (three years) and Denmark (less than one year). This is in line with Garcia-Serrano and Malo (2002), who found that firms with company agreements in Spain had significantly lower turnover than firms under industry agreement. They interpreted this result as a consequence of a 'voice effect': when workers, by means of works councils or union delegations, can express their grievances or demands, they quit less frequently and job tenure is longer.

There is a large difference in job security between the two regimes in Spain: 10 percent of workers under company agreements are employed on fixed-term contracts, as against 26 percent of those under industry agreements. In Belgium and Denmark, the proportion employed on fixed term contracts does not exceed three percent in either regime. The number of employees is, on average, significantly larger in firms that sign their own collective agreement in all three countries, perhaps because workers are generally better organized in large firms. Finally, we see that firms in Belgium and Spain are more often publicly owned when there is a single-employer agreement. According to Dominguez and RodriguezGutiérez (2004), the proportion of trade union members is greater when the firm is publicly owned in Spain. In our sample, all firms in both regimes are privately owned in Denmark.

\section{Estimation}

\section{Estimation Procedure}

A comparison of simple statistics, as in the previous section, does not adequately measure the effect of the bargaining regime on wage structure. Indeed, differences in characteristics between the two regimes may bias results. Therefore, in order to estimate the 'pure' effect of the bargaining regime, we must control for the differences in characteristics, using a more complex estimation procedure. In the remainder of this section we present a non-technical explanation of our estimation procedure. The equations are given in the technical appendix.

The bargaining regime has an effect on the wage structure because there are differences in the monetary return of firms' and workers' characteristics between the two regimes. For example, industry wage rates are 
generally independent of the size of the firm. On the other hand, many studies have shown there to be a correlation between actual wages and company size. Hence, there would be larger wage differentials between firms of different sizes (in economic terms: a higher return to firm size) among those covered by a single-employer agreement than among those that pay the sectoral rate. This will affect the wage structure: larger wage differentials between firms contribute to a larger dispersion of wages.

Therefore, we base our measurements of the wage structure effects of the bargaining regime on the differences in returns to firms' and workers' characteristics between the two regimes. We estimate separate wage equations by bargaining regime in order to obtain estimates of the returns of several characteristics for each. Those characteristics are: seniority (in years), potential experience (years since completing education), level of education (in years), gender, types of employment contract (fixed/unlimited, full/part-time), whether a worker supervises the work of co-workers, shift, night or weekend working, overtime working, occupation (ISCO two-digit category), firm size (number of employees in the establishment), form of financial control (private, semi-private, public), region of the establishment and industry affiliation (NACE rev.1, two-digit category). Those estimates are used to compute an estimation of:

- the difference in average wages between the two regimes;

- the difference in the standard deviation of wages between the two regimes;

- the difference in inter-decile (90-10, 90-50 and 50-10) wage differentials between the two regimes.

\section{Wage Equations}

We begin by analysing the results of the wage equations estimated separately for workers covered by single-employer and by multi-employer bargaining. The large $R^{2}$ indicates that the variables used in the estimation explain the determination of wages to a great extent, and the signs of the coefficients are in line with theoretical expectations.

More interesting are the differences in coefficients between the two regimes. Among human capital variables, only the return to potential experience exhibits no significant difference between the two regimes for any of the three countries. The return to seniority is smaller under singleemployer agreements in Belgium and Spain (by respectively 0.2 and 0.4 percent). But it is larger by 0.8 percent under single-employer agreements in Denmark. This is in line with the study by Bingley and WestergaardNielsen (2003), who found that the return to tenure has increased since bargaining decentralization began in the 1990s. Their explanation is that tenure was very low in Denmark, compared to the other OECD countries. ${ }^{6}$ Employers have taken the opportunity afforded by a more decentralized 
system to raise the return to tenure in order to increase the attachment of workers to their firms. Decentralized bargaining seems to reward better human capital characteristics in Belgium and Denmark, as shown by the difference in the coefficient of years of education. The difference is not statistically significant in Spain. The wage penalty for female workers is smaller (by two percent) under single-employer agreements in Spain, where the gender wage gap under multi-employer bargaining is very wide (20 percent, compared to 16 percent in Belgium and nine percent in Denmark), so unions may want to close this gap through single employer agreement. Singleemployer agreements increase the gender wage gap in Denmark (by one percent), but the gap under this regime is still lower than in the two other countries. The difference is not statistically significant in Belgium.

An analysis of the effects of the bargaining regimes on wage differentials between occupations reveals interesting results. The occupation of reference is 'machine operators and assemblers', the largest blue-collar group. In Denmark, 12 occupations increase their position relative to the reference when there is a single-employer agreement in addition to the sectoral agreement. Most of these are white-collar, and eight were already better paid than the reference when only a multi-employer agreement was in place. Conversely, two of the three occupational groups whose positions worsened under a single-employer agreement are blue-collar. Hence it seems that, in Denmark, single-employer agreements widen the interoccupation wage differentials and mostly benefit white-collar workers. In Spain, by contrast, single-employer agreements seem to reduce the differentials between occupations: the three groups that have a better position under single-employer agreements are paid less than or equal to the reference under multi-employer agreements. Conversely, the four groups that have a worse position under single-employer agreements are better paid than the reference under multi-employer agreements; three of these are white-collar. This may be explained by trade union efforts in company bargaining to increase the relative wages of their members who are traditionally low-paid and unskilled. Surprisingly, it seems that in Belgium also, singleemployer agreements reduce wage differentials between occupations. Five out of the six groups that have improved their position by being covered by a single-employer agreement in addition to the sectoral agreement were paid less than the reference under multi-employer agreements. The opposite is true for the two groups that have worsened their position.

The return to firm size is larger under single-employer agreements in Belgium and in Denmark. This indicates for those two countries that firm-specific characteristics (at least size) are better taken into account under single-employer agreements. The fact that the reverse is found in Spain may be a sign of the union policy of wage standardization between firms. Finally, we observe that in Spain, the wage penalty relative to the reference region 'East' is larger under multi-employer agreements than 
under single-employer agreements in four regions. The difference is not statistically significant for the two other regions. So regional wage differentials seem to be larger under multi-employer than under singleemployer agreements in Spain. This may be explained by the fact that multi-employer agreements are often regional or provincial, while singleemployer agreements may cover large firms that have establishments in different regions, thus setting the same wages for the different regional establishments.

\section{Effect of the Bargaining Regime on Wage Levels}

Table 1 shows that wages are on average higher under single-employer agreements, even if we control for differences in observed characteristics. The wage differentials are around four percent without statistically significant differences between the countries. This result is not surprising for Belgium and Denmark because single-employer agreements can only increase the wages set at higher levels. It is in the range of previous findings for multi-level bargaining systems: 4.4 and 7.5 percent respectively for blueand white-collar workers in Italy (Dell'Aringa and Lucifora, 1994a), 0.5 percent in the Netherlands (Hartog et al., 2002), 5.1 percent in Belgium (Rycx, 2003) and 1.6 percent in Portugal (Cardoso and Portugal, 2003). In Spain, because company agreements are not constrained by sectoral agreements, this result may be due to stronger union bargaining power in companies covered by a company agreement. It is line with the wage differential of five percent found by Palenzuela and Jimeno (1996).

\section{Effect of the Bargaining Regime on Wage Dispersion}

Our estimations show (Table 2) that, other things being equal, singleemployer agreements increase the standard deviation of wages in Denmark by 0.022 relative to multi-employer agreements. In Belgium, single-employer agreements increase the standard deviation by 0.004 . In Spain, by contrast, the standard deviation is smaller by 0.027 under singleemployer agreements. Similar results are found when we analyse the

TABLE 1. Average Log Wage Differential between Single-employer and Multi-Employer Agreements (Standard Errors in Parentheses)

\begin{tabular}{lll}
\hline Belgium & Denmark & Spain \\
\hline $0.041 \% * \%$ & $0.031 \% * \%$ & $0.041^{* * * *}$ \\
$(0.006)$ & $(0.003)$ & $(0.006)$ \\
\hline
\end{tabular}

$* p<0.10 ; * p<0.05 ; * * * p<0.001$.

Source: ESES 1995. 
effect of the bargaining regime on the 90-10 percentile wage differential. Controlling for differences in characteristics, single-employer agreements increase this differential by 0.022 and 0.083 respectively in Belgium and in Denmark, but reduce it by 0.077 in Spain. The comparison of the effect of the bargaining regime on the 50-10 and on the 90-50 percentile differentials shows that, in Denmark, this effect is similar (0.042) in the lower and in the upper parts of the wage distribution. In Belgium, the increase in wage dispersion is only due to an increase $(0.023)$ in the upper half of the wage distribution. Company agreements in fact very slightly reduce (by 0.001) the wage dispersion in the lower half. In Spain, almost all the reduction in wage dispersion takes place in the lower half of the wage distribution $(0.071$ in the lower part and 0.005 in the upper part). This may mean that the wage gains from coverage by a single-employer agreement benefit most particularly the workers whose wages are below the median, which, again, may be attributed to trade union policy.

To sum up, single-employer agreements, as compared with multiemployer agreements, increase wage dispersion in Denmark and Belgium and reduce it in Spain. The effects are very small in Belgium. In relative terms, single-employer agreements increase the standard deviation of wages by one percent and the $90-10$ percentile wage differential by three percent. The effects are greater in Denmark and in Spain. In the former, single-employer agreements increase the standard deviation by seven percent and the $90-10$ percentile differential by 12 percent. In the latter, singleemployer agreements reduce the standard deviation by six percent and the 90-10 percentile differential by seven percent. The more limited effects in Belgium may be due to the fact that opposing forces cancel each other out. Firm size and education, for instance, have higher returns under company agreements, while the opposite occurs for tenure and occupation. Another explanation is strict government control over wage-setting since 1981, limiting wage cost increases. The automatic indexation of wages and multiemployer wage increases already account for a substantial part of the authorized wage increase (from 1983 to 1986, no other increases were authorized). So the small difference in wage dispersion between single- and multi-employer agreements can be explained by the fact that Belgian firms have little freedom for their wage policies.

\section{Conclusion}

This article has examined the effect of the bargaining regime on the wage structure in Belgium, Denmark and Spain, using a harmonized matched employer-employee dataset. In all three countries most workers, irrespective of their union status, are covered by a multi-employer agreement. 


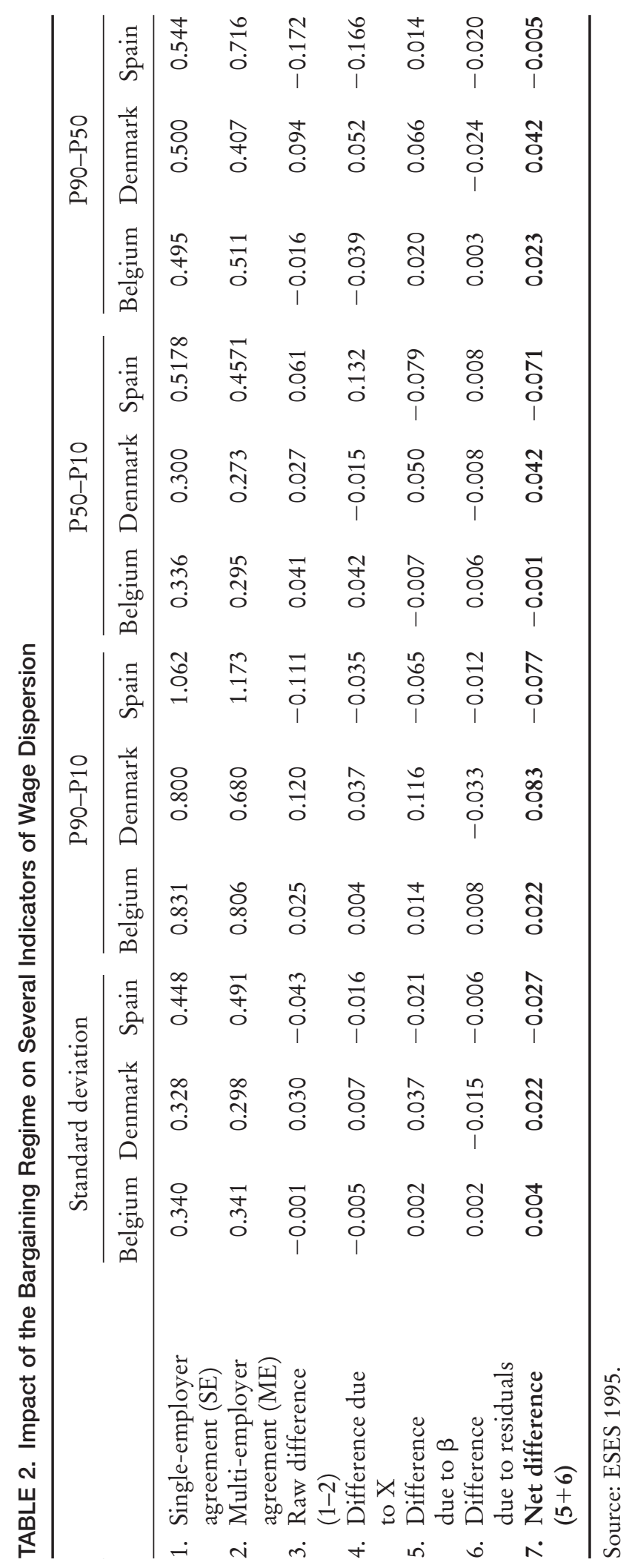


In Belgium and Denmark, multi-employer agreements set industry or national standards for specified categories of workers that are defined on the basis of a limited number of criteria such age, experience and occupation. Bargaining at company level may then increase wages above the sectoral standard. Our estimations show that in both countries, both the level and the dispersion of wages are higher for workers covered by singleemployer agreements, compared to workers covered only by multiemployer agreements. This reflects the fact that single-employer agreements cannot set lower wages than agreements at the higher level. The increase in wage dispersion may come from two sources. First, company agreements may increase inter-firm wage differentials because they take into account firm specificities which are not among the criteria that define multiemployer standards. The comparison of wage equation coefficients between the two regimes does indeed show that firm size has a greater effect on wages under single-employer agreements. For Belgium, our results are in line with Rycx (2003), who finds a larger dispersion of inter-industry wage differentials for firms covered by a company agreement. Second, a company agreement may increase the within-firm wage dispersion, because many single-employer agreements signed since the decentralization trend in the 1990s have been initiated by employers in order to introduce more pay flexibility and wider differentials in their firms. From the comparison of wage equation estimates, we find larger differentials between workers with a different tenure, education level, occupation and gender under singleemployer agreements in Denmark. This may be linked to the generalized practice of 'pay-sum' bargaining, where only the aggregate increase at firm-level is determined by collective bargaining and its allocation among workers is left to the employer. For Belgium, the effect on the within-firm dispersion is uncertain: although single-employer agreements increase the return to education, they also reduce the return to tenure and the wage differentials between occupations.

In Spain, single-employer agreements constitute a bargaining regime independent of industry agreements. Following the 'no competition' principle, the two regimes deal with the same types of subject and there is no division of responsibility between them. Therefore, single-employer agreements may set wages above or below industry standards. By contrast with Belgium and Denmark where many company agreements are initiated by the employer, the majority of single-employer agreements in Spain are initiated by works councils or trade union delegations: average union density in firms covered by a single-employer agreement is much greater than in firms covered by an industry agreement. Multi-employer agreements are also less binding on companies than single-employer agreements. Therefore, the differences in wage structure between the two bargaining regimes resemble the differences between the union and non-union sectors 
in Anglo-Saxon countries. Higher wages and lower wage dispersion are found under company bargaining. The lower wage dispersion seems to result from a reduction in the wage dispersion both within and between firms. Comparison of wage equation coefficients between the two regimes indeed shows lower wage differentials between occupations, gender, tenure and firm size under the firm agreement regime. The regional dimension of collective bargaining may constitute a complementary explanation to this compression effect. Industry agreements have, on the whole, local (regional or provincial) scope in Spain, while a company agreement may apply to establishments in different regions or provinces. We do indeed observe that the regional coefficients in the firm agreement wage equation are lower than in the industry agreement wage equation. Our results confirm and complete the findings of Dominguez and Rodriguez-Gutiérez (2004) who find that company agreements compress the within-firm wage dispersion in Spain.

We conclude that single-employer agreements are mainly used in Denmark and Belgium to adapt pay to the specificities of the firm and to local economic conditions. In Spain, they are mainly used by unions to raise wages and to compress the wage distribution. Note that this does not imply that, in Spain, the industry wage rates are more dispersed than the wages set by single-employer agreements. It may be that, because of the less binding nature of sectoral agreements, firms covered by these have more freedom to set wages and, because unions are weak in these firms, can impose a very dispersed wage structure. It would be interesting to see if results would be different with data on negotiated rates of pay rather than actual pay.

Future research concerning the effect of the bargaining regime on the wage structure should control for a potential selectivity effect, that is, for the fact that firms or workers in a particular bargaining regime might not be representative of the overall sample. However, as pointed out by Hartog et al. (1997: 7), this will remain a very difficult task 'as long as no (satisfactory) independent variables to control for the endogeneity of the bargaining regime are available'.

\section{ACKNOWLEDGEMENTS}

This article has evolved form earlier drafts presented at workshops in Mannheim (LoWER annual conference 2005), San Francisco (SOLE/EALE 2nd world conference) and Brussels (DULBEA). We thank all seminar participants and more particularly Michael Burda, Claudio Lucifora and Fernando Valdès Dal-Ré for their comments and suggestions. We also thank the two anonymous reviewers and Richard Hyman for their useful comments. This article is produced as a part of a TSER program on Pay Inequalities and Economic Performance (PIEP) financed by the European Commission (Contract No HPSE-CT-1999-00 040). 


\section{NOTES}

1 We thank an anonymous referee for this information.

2 This implies that average union density in firms covered by an industry agreement is only seven percent.

3 It includes all economic activities falling within NACE Rev. 1 categories $\mathrm{C}$ to $\mathrm{K}$.

4 We thank one of the referees for highlighting this problem.

5 Complete descriptive statistics and wage equations are available in Plasman et al. (2006).

6 With an average tenure of 7.9 years, Denmark is on a level with the Anglo-Saxon countries. It is also among the countries with the lowest fraction of those with more than 10 years of tenure (Bingley and Westergaard-Nielsen, 2003).

\section{REFERENCES}

Andersen, T.M. (2003) 'Changes in Danish Labor Market Bargaining: The Prototypical Case of Organized Decentralization?’, in E.J. Dølvik and F. Engelstad (eds) National Regimes of Collective Bargaining in Transformation: Nordic Trends in a Comparative Perspective, Makt- og demokratiutredningens rapportserie 54. Oslo: Institute for Social Research.

Andersen, S.K. and Mailand, M. (2005) 'The Danish Flexicurity Model. The Role of the Collective Bargaining System', FAOS Working Paper, FAOS, Copenhagen.

Bingley, P. and Westergaard-Nielsen, N. (2003) Returns to Tenure: Firm and Worker Heterogeneity. London: Comparative Analysis of Enterprise (Micro) Data Conference Program.

Blau, F.D. and Kahn, L.M. (2002) At Home and Abroad. U.S. Labor-Market Performance in International Perspective. New York: Russell Sage Foundation.

Cardoso, A.R. and Portugal, P. (2003) 'Bargained Wages, Wage Drift and the Design of the Wage Setting System’, IZA Discussion Paper No 914, IZA, Bonn.

Checchi, D. and Pagani, L. (2004) 'The Effects of Unions on Wage Inequality. The Italian Case in the Nineties', PIEP Working Paper, Centre for Economic Performance, London.

Dell'Aringa, C. and Lucifora, C. (1994a) 'Collective Bargaining and Relative Earnings in Italy', European Journal of Political Economy 10: 727-47.

Dell'Aringa, C. and Lucifora, C. (1994b) 'Wage Dispersion and Unionism: Do Unions Protect Low Pay?', International Journal of Manpower 15(2/3): 150-70.

Dell'Aringa, C., Lucifora, C., Orlando, N. and Cottini, E. (2004) 'Bargaining Structure and Intra-Establishment Pay Inequality in Four European Countries: Evidence from Matched Employer-Employee Data', PIEP Working Paper, Centre for Economic Performance, London. 
Dominguez, J.F.C and Rodriguez-Gutiérez, C. (2004) 'Collective Bargaining and Within-firm Wage Dispersion in Spain', British Journal of Industrial Relations 42(3): 481-506.

EIRO (1997) 'The 1997 Labour Reform in Spain: The April Agreements', available online at: [http://www.eiro.eurofound.eu.int/1997/06/feature/es9706211f.html].

European Commission (2004) Industrial Relations in Europe. Luxembourg: Office for Official Publications of the European Communities.

Freeman, R.B. (1980) 'Unionism and the Dispersion of Wages', Industrial and Labor Relations Review 34(1): 3-23.

Garcia-Serrano, C. and Mallo, M.A. (2002) 'Worker Turnover, Job Turnover and Collective Bargaining in Spain', British Journal of Industrial Relations 40(1): 69-85.

Hartog, J., Leuven, E. and Teulings, C. (1997) 'Wages and the Bargaining Regime in a Corporatist Setting: The Netherlands', Discussion Paper No. 1706, Centre for Economic Policy Research, London.

Hartog, J., Leuven, E. and Teulings, C. (2002) 'Wages and the Bargaining Regime in a Corporatist Setting: The Netherlands', European Journal of Political Economy 18: 317-31.

Hibbs, H.A. Jr and Locking, H. (1996) 'Wage Compression, Wage Drift and Wage Inflation in Sweden', Labour Economics 3: 109-41.

Izquierdo, M., Moral, E. and Urtasun, A. (2003) 'Collective Bargaining in Spain: An Individual Data Analysis’, Documento Occasional No. 0302, Banco de Espana, Madrid.

Juhn, C., Murphy, M. and Pierce, B. (1993) 'Wage Inequality and the Rise in Returns to Skills', The Journal of Political Economy 101(3): 410-42.

Lazear, E.P. and Rosen, S. (1981) 'Rank-Order Tournament as Optimum Labor Contracts', Journal of Political Economy 89: 841-64.

OECD (2004) Employment Outlook. Paris: OECD.

Palenzuela, D.R. and Jimeno, J.F. (1996) 'Wage Drift in Collective Bargaining at the Firm Level: Evidence From Spain', Annales d'Economie et de Statistique 41/2: 187-206.

Plasman, R., Rusinek, M. and Rycx, F. (2006) 'Wages and the Bargaining Regime under Multi-Level Bargaining: Belgium, Denmark and Spain', IZA Discussion Paper No 1990, IZA, Bonn.

Rodriguez-Gutiérez, C. (2001) 'Wage Dispersion Within Firms and Collective Bargaining in Spain', Economics Letters 72: 381-6.

Rycx, F. (2003) 'Industry Wage Differentials and the Bargaining Regime in a Corporatist Country', International Journal of Manpower 24(4): 347-66.

Stewart, M.B. (1987) 'Collective Bargaining Arrangements, Closed Shops and Relative Pay’, Economic Journal 97(385): 140-56.

Teulings, C. and Hartog, J. (1998) Corporatism or Competition? Labour Contracts, Institutions and Wage Structures in International Comparison. Cambridge: Cambridge University Press.

Toharia, L. (1986) 'Un Fordisme Inachevé, entre Transition Politique et Crise Economique: l'Espagne', in R. Boyer (eds) La Flexibilité du Travail en Europe, pp. 131-51. Paris: La Découverte. 
Traxler, F., Blaschke, S. and Kittel, B. (2001) National Labour Relations in Internationalized Markets. A Comparative Study of Institutions, Change, and Performance. New York: Oxford University Press.

Van Ruysseveldt, J. and Visser, J. (1996) 'Weak Corporatisms Going Different

Ways? Industrial Relations in the Netherlands and Belgium', in J. Van

Ruysseveldt and J. Visser (eds) Industrial Relations in Europe. Traditions and Transitions, pp. 205-64. London: Sage.

Wallerstein, M. (1999) 'Wage-Setting Institutions and Pay Inequality in Advanced Industrial Societies', American Journal of Political Science 43(3): 649-80.

White, H. (1980) 'A Heteroscedasticity Consistent Covariance Matrix Estimator and a Direct Test for Heteroscedasticity’, Econometrica 48: 817-30.

\section{TECHNICAL APPENDIX}

\section{Wage Equations by Bargaining Regime}

$$
\begin{aligned}
& \ln W_{i}^{S E}=X_{i}^{S E} \beta^{S E}+e_{i}^{S E} \\
& \ln W_{i}^{M E}=X_{i}^{M E} \beta^{S E}+e_{i}^{M E}
\end{aligned}
$$

$\mathrm{W}_{\mathrm{i}}$ is the wage of the ith worker in each bargaining regime (single-employer bargaining (SE) and multi-employer bargaining $(\mathrm{ME})$ ). $X$ is a vector of worker, firm and job characteristics. $\beta$ is the vector of the coefficients (i.e. the returns of the characteristics) to be estimated and $e_{i}$ is the error term. Those wage equations are estimated by ordinary least squares with White (1980) heteroscedasticity consistent standard errors.

\section{Difference in Mean Wages between the Two Regimes}

$$
\overline{\ln W_{i}^{S E}}-\overline{\ln W_{i}^{M E}}=\hat{\beta}^{M E}{ }^{\prime}\left(\bar{X}^{S E}-\bar{X}^{M E}\right)+\bar{X}^{S E}{ }^{\prime}\left(\hat{\beta}^{S E}-\hat{\beta}^{M E}\right)
$$

$\bar{X}^{S E}$ and $\bar{X}^{M E}$ are the vectors of mean characteristics respectively across the SE and the $\mathrm{ME}$ workers. The first component on the right-hand side of the equation is the difference in mean wages that is due to differences in observed characteristics between the two regimes. The second component is the difference in mean wages that is due to differences in the wage equations coefficients between the two regimes. Following Stewart (1987), we consider this last component as the effect of the bargaining regime on average wages. Said differently, it measures the impact on the average wage of the differences in the returns of observed firms' and workers' characteristics between the two regimes. Standard errors from Stewart (1987) are used for the statistical inferences.

\section{Difference in Wage Dispersion between the Two Regimes}

In order to estimate the effect of the bargaining regime on the wage dispersion, we use the method of Juhn et al. (1993). This method consists in constructing wage counterfactuals for each individual, and then computing distributional 
statistics from the counterfactual wage distributions obtained. First, we must express equations (1) and (2) in the following forms:

$$
\begin{aligned}
& \ln W_{i}^{S E}=X_{i}^{S E} \beta^{S E}+F_{S E}^{-1}\left(\theta_{i}^{S E}\right) \\
& \ln W_{i}^{M E}=X_{i}^{M E} \beta^{M E}+F_{M E}^{-1}\left(\theta_{i}^{M E}\right)
\end{aligned}
$$

where $F_{S E}^{-1}\left(\theta_{i}^{S E}\right)=e_{i}^{S E}$ and $F_{M E}^{-1}\left(\theta_{i}^{M E}\right)=e_{i}^{M E} ; F_{S E}^{-1}$ and $F_{M E}^{-1}$ are the inverse of the cumulative distribution of the residuals respectively in the $\mathrm{SE}$ and in the $\mathrm{ME}$ sample; $\theta_{i}$ is the rank of the residual of the $i^{\text {th }}$ individual in the residual distribution. Then, we construct two types of counterfactual wages for each SE worker:

$$
\begin{aligned}
& \ln W_{i}^{S E(1)}=X_{i}^{S E} \beta^{M E}+F_{S E}^{-1}\left(\theta_{i}^{S E}\right) \\
& \ln W_{i}^{S E(2)}=X_{i}^{S E} \beta^{M E}+F_{M E}^{-1}\left(\theta_{i}^{S E}\right)
\end{aligned}
$$

$\ln W_{i}^{S E(1)}$ is the log wage of the SE workers if they were remunerated like the ME workers and is obtained by using the coefficients from the earnings equation estimated in ME sample; $\ln W_{i}^{S E(2)}$ is the log wage of the SE workers if, in addition, their residuals were distributed as for the ME workers. Once we have these four $\log$ wage distributions $\left(\ln W^{\mathrm{ME}} ; \ln W^{\mathrm{ME}} ; \ln W^{\mathrm{SE}(1)} ; \ln W^{\mathrm{SE}(2)}\right)$, we can construct distributional statistics for each of them. Consider the statistics $G$ (e.g. $G=$ standard deviation, P90-P10, P50-P10 or P90-P50). The difference in G between SE and ME may be decomposed into three components:

$$
\begin{aligned}
G\left(\ln W^{S E}\right)-G\left(\ln W^{M E}\right) & =G\left(\ln W^{S E(2)}\right)-G\left(\ln W^{M E}\right) \\
& +G\left(\ln W^{S E}\right)-G\left(\ln W^{S E(1)}\right) \\
& +G\left(\ln W^{S E(1)}\right)-G\left(\ln W^{S E(2)}\right)
\end{aligned}
$$

The first component on the right-hand side of the equation is the difference in $G$ due to differences in observed and unobserved characteristics (it corresponds to row 4 in table 2); the second is the difference in $G$ due to differences in wage equation coefficients, i.e. the difference in the returns of the observed characteristics (row 5); the third is the difference in $G$ due to differences in the returns of unobserved characteristics (row 6). We define the effect of the bargaining regime on $G$ as the sum of the two last components, so the difference in $G$ that is due to differences in the returns of observed and unobserved characteristics (row 7). We estimate the effect of the bargaining regime on the standard deviation, the 90-10, the $90-50$ and the 50-10 percentile differentials.

ROBERT PLASMAN is Professor of Economics, Labour Economics and Industrial Relations at Université Libre de Bruxelles and co-director of the Department of Applied Economics (DULBEA). ADDRESS: 50, Avenue F.D. Roosevelt, 1050 Brussels, Belgium. [e-mail: rplasma@ulb.ac.be] 
MICHAEL RUSINEK is PhD candidate in Economics at Université Libre de Bruxelles and is affiliated to DULBEA. [e-mail: mirusine@ulb.ac.be] FRANÇOIS RYCX is Professor of Economics, Labour Economics and Econometrics at Université Libre de Bruxelles. He is affiliated to DULBEA and a research fellow of the Institute for the Study of Labor (IZA). [e-mail: frycx@ulb.ac.be] 